\title{
ELECTROPHORETIC AND CHEMICAL ANALYSIS OF PROTEIN IN NEPHRITIC URINE ${ }^{1}$
}

\author{
By S. S. BLACKMAN, JR., AND BERNARD D. DAVIS \\ (From the Department of Pathology and the Department of Medicine of the Johns Hopkins \\ University and the Johns Hopkins Hospital, Baltimore)
}

(Received for publication December 10, 1942)

Quantitative chemical determinations of the protein concentration and of the relative proportions of albumin and globulin in the urine of a series of cases of Bright's disease showed that there was a close relationship between high concentrations of globulin on the one hand, and on the other, the rate of progress of renal failure and the collection within glomeruli and tubules of the kidneys of hyaline material which is probably precipitated protein (1). Since these analyses were made by precipitation of protein and macro$\mathrm{Kjeldahl}$ determinations of nitrogen, and since it is said that such precipitation methods are of doubtful value on account of the instability of the biocolloids and their sensitivity to chemical agents (2), it seemed desirable to compare the results of the chemical method with those obtained by the moving boundary electrophoretic method of $\mathrm{Ti}$ selius (2).

\section{THE MATERIAL EXAMINED}

Twenty-two specimens of urine were analyzed by both chemical and electrophoretic methods. Twenty-four-hour specimens were collected in clean dry bottles. Either toluene or thymol was used as preservative. Since it has been found that the small change in $\mathrm{pH}$ of urines collected under these conditions does not appreciably alter the fractionation and subsequent $\mathrm{Kjeldahl}$ determination of nitrogen as previously described (1), no adjustment of $\mathrm{pH}$ was made. The urine was filtered through coarse filter paper before analyses of the protein were begun. The concentration of protein in the 22 specimens varied from 0.450 to 3.450 grams per cent (Kjeldahl determinations).

The urine was obtained from 3 cases of progressing nephrotic nephritis, 1 lipoid nephrosis, and 1 case of multiple myeloma with Bence-Jones proteinuria and renal insufficiency (Table I). The kidney disease did not begin in any of the cases as acute hemorrhagic glomerulonephritis. Renal insufficiency progressed at different rates in the 3 cases of nephrotic nephritis.

${ }^{1}$ Aided by a grant from the Rockefeller Foundation Fluid Research Fund of the School of Medicine of the Johns Hopkins University.
Patient S, after a 2-year period of stationary renal function and occasional globulinuria of high concentration, during the following year developed frequent globulinuria of high concentration (30 to 40 per cent of the total protein), and the urea clearance fell from 38 and 40

TABLE I

Total protein in grams per cent, and the relative percentage of globulin, in 22 nephritic urines, as measured by Kjeldahl and electrophoretic methods

\begin{tabular}{|c|c|c|c|c|c|}
\hline \multirow{2}{*}{ Date } & \multirow{2}{*}{$\underset{\text { tient }}{\text { Pa- }}$} & \multirow{2}{*}{ Diagnosis } & \multirow{2}{*}{$\begin{array}{l}\text { Total protein } \\
\text { (Kjeldahl) }\end{array}$} & \multicolumn{2}{|c|}{$\begin{array}{l}\text { Relative percentage } \\
\text { of globulin }\end{array}$} \\
\hline & & & & Kjeldahl & $\begin{array}{l}\text { Electro- } \\
\text { phoretio }\end{array}$ \\
\hline $\begin{array}{lr}\text { November } & 22,1941 \\
\text { January } & 3,1942 \\
\text { February } & 7,1942 \\
\text { February } & 14,1942 \\
\text { February } & 21,1942 \\
\text { March } & 21,1942 \\
\end{array}$ & $\begin{array}{l}\mathbf{8} \\
\mathbf{8} \\
\mathbf{S} \\
\mathbf{8} \\
\mathbf{8} \\
\mathbf{8}\end{array}$ & $\begin{array}{l}\text { Rapidly pro- } \\
\text { gressing } \\
\text { nephrotic } \\
\text { nephritis }\end{array}$ & $\begin{array}{c}\text { orams per cent } \\
0.563 \\
0.469 \\
0.638 \\
0.575 \\
0.619 \\
0.756\end{array}$ & $\begin{array}{l}31 \\
31 \\
33 \\
40 \\
42 \\
36\end{array}$ & $\begin{array}{l}\mathbf{3 7} \\
\mathbf{3 6} \\
\mathbf{3 6} \\
\mathbf{3 6} \\
\mathbf{3 8} \\
\mathbf{3 1}\end{array}$ \\
\hline 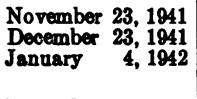 & $\begin{array}{l}\mathbf{Q} \\
\mathbf{Q} \\
\mathbf{Q}\end{array}$ & $\begin{array}{l}\text { Rapidly pro- } \\
\text { greesing } \\
\text { nephrotio } \\
\text { nephritis }\end{array}$ & $\begin{array}{l}0.856 \\
1.169 \\
0.669\end{array}$ & $\begin{array}{l}35 \\
38 \\
36\end{array}$ & $\begin{array}{l}39 \\
39 \\
38\end{array}$ \\
\hline $\begin{array}{lr}\text { January } & 3,1942 \\
\text { January } & 24,1942 \\
\text { February } & 7,1942 \\
\text { February } & 14,1942 \\
\text { February } & 21,1942\end{array}$ & $\begin{array}{l}\mathbf{M} \\
\mathbf{M} \\
\mathbf{M} \\
\mathbf{M}\end{array}$ & $\begin{array}{l}\text { Slowly pro- } \\
\text { greseing } \\
\text { nephrotio } \\
\text { nephritis }\end{array}$ & $\begin{array}{l}0.581 \\
0.581 \\
0.600 \\
0.450 \\
0.538\end{array}$ & $\begin{array}{l}21 \\
31 \\
31 \\
31 \\
29\end{array}$ & $\begin{array}{l}24 \\
27 \\
29 \\
27 \\
31\end{array}$ \\
\hline $\begin{array}{lr}\text { January } & 26,1942 \\
\text { February } & 1,1942 \\
\text { February } & 7,1942 \\
\text { February } & 22,1942\end{array}$ & $\begin{array}{l}\hat{A} \\
\hat{A}\end{array}$ & $\begin{array}{l}\text { Lipoid } \\
\text { nephrosis. } \\
\text { Normal re- } \\
\text { nal function }\end{array}$ & $\begin{array}{l}3.031 \\
2.225 \\
3.450 \\
2.225\end{array}$ & $\begin{array}{l}20 \\
17 \\
22 \\
21\end{array}$ & $\begin{array}{l}18 \\
17 \\
19 \\
17\end{array}$ \\
\hline $\begin{array}{lr}\text { September } & 7,1941 \\
\text { October } & 1,1941 \\
\text { October } & 10,1941 \\
\text { January } & 0,1942\end{array}$ & $\begin{array}{l}\mathbf{T} \\
\mathbf{T} \\
\mathbf{T}\end{array}$ & $\begin{array}{l}\text { Multiple } \\
\text { myeloma } \\
\text { and pro- } \\
\text { gresgive } \\
\text { renal in- } \\
\text { sufficiency }\end{array}$ & $\begin{array}{l}0.519 \\
0.563 \\
0.744 \\
0.475\end{array}$ & $\begin{array}{r}97 \\
100 \\
95 \\
92\end{array}$ & $\begin{array}{l}100 \\
100 \\
99+ \\
93\end{array}$ \\
\hline
\end{tabular}

to 3 and 3 per cent of normal standard. She died in uremia soon afterwards (blood N.P.N., $184 \mathrm{mgm}$. per cent).

The urine of patient $Q$, during a period of 17 months, always contained high concentrations of globulin (30 to 50 per cent of the total protein, usually). At the beginning of this period, the urea clearance was 55 and 48 per cent of normal standard and the blood N.P.N., 30 mgm. per cent. Before she died in uremia, the N.P.N. reached $176 \mathrm{mgm}$. per cent. Urea clearance was not done.

The renal function of patient $M$ was apparently stationary for 2 years and the urine contained high concentrations of globulin on few occasions. During the following year, high concentrations of globulin (30 to 33 
per cent of the total, generally) began to appear fairly often, and the renal function decreased somewhat (blood N.P.N. rose from 44 to $60 \mathrm{mgm}$. per cent).

The patient with lipoid nephrosis (Table I, patient A) has maintained normal urea clearance and blood N.P.N. for over 2 years, and globulin concentrations in the urine as high as 30 per cent of the total protein have rarely occurred.

The diagnosis of multiple myeloma (patient $\mathrm{T}$ ) was confirmed by sternal puncture. The patient died with a high degree of renal insufficiency about a year after the onset of symptoms (blood N.P.N., $156 \mathrm{mgm}$. per cent and urea clearance, 3 and 4 per cent of normal standard 2 months before death).

\section{METHODS}

The chemical method. The chemical method which was used is a modified Howe analysis. Total protein was precipitated by means of trichloroacetic acid; globulin by a 4.05 molar potassium phosphate mixture (3). Nitrogen determinations were made by the macro-Kjeldahl method. The technique employed in precipitation of the urinary proteins, determination of nitrogen, calculation of total protein, albumin, and globulin, and the limitations of these methods have already been described in detail (1). They need not be repeated here.

The electrophoretic method. The electrophoretic analyses were performed by the Longsworth (4) modification of the apparatus of Tiselius. Urinary proteins were precipitated by saturation with ammonium sulfate, filtered, redissolved, and dialyzed in running tap water until essentially free of ammonia. They were then dialyzed against a barbital buffer of ionic strength 0.1 and $\mathrm{pH} 8.5$. Under these conditions, the pattern of proteins consists of albumin and the usual 3 globulin components (alpha, beta, and gamma), plus a component not ordinarily seen at a less alkaline $\mathrm{pH}$, which has been denoted as alpha ${ }_{1}$ globulin $\left(a_{1}\right)$ by Longsworth (5). Since it has been found by one of us (6) on fractional salting-out of serum that this component $\left(a_{1}\right)$ is even more soluble than electrophoretic "albumin," we have included it in the present urinalyses with the "albumin" fraction, and have considered the sum of the usual $a, \beta$, and $\gamma$ fractions as the "true" percentage of globulin.

The electrophoretic measurements were made of the ascending pattern, since irregular refractive effects at the descending beta peaks interfered with the measurements there.

\section{RESULTS}

The results are shown in Table I. The 2 methods gave values for globulin which agreed closely in their order of magnitude. Neither method gave consistently higher or lower values. In 10 specimens, a slightly higher result was obtained by the

TABLE II

Electrophoretic fractionation of 22 nephritic urines

\begin{tabular}{|c|c|c|c|c|c|c|c|c|c|}
\hline \multirow{3}{*}{ Date } & \multirow{3}{*}{ Patient } & \multirow{3}{*}{ Diagnosis } & \multirow{3}{*}{$\begin{array}{l}\text { Total protein } \\
\text { (Kjeldahl) }\end{array}$} & \multicolumn{6}{|c|}{ Concentrations (per cent of total) } \\
\hline & & & & \multirow{2}{*}{ Albumin } & \multicolumn{5}{|c|}{ Globulins } \\
\hline & & & & & Total & Alpha & Beta & Gamma & Fibrinogen \\
\hline $\begin{array}{lr}\text { November } & 22,1941 \\
\text { January } & 3,1942 \\
\text { February } & 7,1942 \\
\text { February } & 14,1942 \\
\text { February } & 21,1942 \\
\text { March } & 21,1942\end{array}$ & $\begin{array}{l}\mathbf{S} \\
\mathbf{S} \\
\mathbf{S} \\
\mathbf{S} \\
\mathbf{S} \\
\mathbf{S}\end{array}$ & $\begin{array}{l}\text { Rapidly progress- } \\
\text { ing nephrotic } \\
\text { nephritis }\end{array}$ & $\begin{array}{c}\text { grams per cent } \\
0.563 \\
0.469 \\
0.638 \\
0.575 \\
0.619 \\
0.756\end{array}$ & $\begin{array}{l}63.4 \\
64.4 \\
64.4 \\
64.0 \\
62.5 \\
69.0\end{array}$ & $\begin{array}{l}36.6 \\
35.6 \\
35.6 \\
36.0 \\
37.5 \\
31.0\end{array}$ & $\begin{array}{l}6.0 \\
8.9 \\
7.4 \\
8.7 \\
9.2 \\
4.8\end{array}$ & $\begin{array}{r}11.2 \\
8.9 \\
10.4 \\
9.0 \\
9.2 \\
10.2\end{array}$ & $\begin{array}{l}19.4 \\
17.8 \\
17.8 \\
18.3 \\
19.1 \\
16.0\end{array}$ & $\begin{array}{l}0 \\
0 \\
0 \\
0 \\
0 \\
0\end{array}$ \\
\hline $\begin{array}{lr}\text { November } & 23,1941 \\
\text { December } & 23,1941 \\
\text { January } & 4,1942\end{array}$ & $\begin{array}{l}\mathbf{Q} \\
\mathbf{Q} \\
\mathbf{Q}\end{array}$ & $\begin{array}{l}\text { Rapidly progress- } \\
\text { ing nephrotic } \\
\text { nephritis }\end{array}$ & $\begin{array}{l}0.956 \\
1.169 \\
0.669\end{array}$ & $\begin{array}{l}61.5 \\
61.5 \\
62.3\end{array}$ & $\begin{array}{l}38.5 \\
38.5 \\
37.7\end{array}$ & $\begin{array}{l}4.5 \\
3.4 \\
3.9\end{array}$ & $\begin{array}{r}12.0 \\
10.3 \\
9.4\end{array}$ & $\begin{array}{l}22.0 \\
24.8 \\
24.4\end{array}$ & $\begin{array}{l}\mathbf{0} \\
\mathbf{0} \\
\mathbf{0}\end{array}$ \\
\hline $\begin{array}{lr}\text { January } & 3,1942 \\
\text { January } & 24,1942 \\
\text { February } & 7,1942 \\
\text { February } & 14,1942 \\
\text { February } & 21,1942\end{array}$ & $\begin{array}{l}\mathbf{M} \\
\mathbf{M} \\
\mathbf{M} \\
\mathbf{M} \\
\mathbf{M}\end{array}$ & $\begin{array}{l}\text { Slowly progressing } \\
\text { nephrotic } \\
\text { nephritis }\end{array}$ & $\begin{array}{l}0.581 \\
0.581 \\
0.600 \\
0.450 \\
0.538\end{array}$ & $\begin{array}{l}75.8 \\
72.9 \\
71.5 \\
73.5 \\
69.1\end{array}$ & $\begin{array}{l}24.2 \\
27.1 \\
28.5 \\
26.5 \\
30.9\end{array}$ & $\begin{array}{r}8.3 \\
10.0 \\
9.1 \\
8.7 \\
9.1\end{array}$ & $\begin{array}{r}8.7 \\
9.1 \\
9.5 \\
9.1 \\
11.5\end{array}$ & $\begin{array}{r}7.2 \\
8.0 \\
9.9 \\
8.7 \\
10.3\end{array}$ & $\begin{array}{l}0 \\
0 \\
0 \\
0 \\
0\end{array}$ \\
\hline $\begin{array}{lr}\text { January } & 26,1942 \\
\text { February } & 1,1942 \\
\text { February } & 7,1942 \\
\text { February } & 22,1942\end{array}$ & $\begin{array}{l}\text { A } \\
\text { A } \\
\text { A } \\
\text { A }\end{array}$ & $\begin{array}{l}\text { Lipoid nephrosis. } \\
\text { Normal renal } \\
\text { function }\end{array}$ & $\begin{array}{l}3.031 \\
2.225 \\
3.450 \\
2.225\end{array}$ & $\begin{array}{l}81.8 \\
82.7 \\
80.6 \\
82.6\end{array}$ & $\begin{array}{l}18.2 \\
17.3 \\
19.4 \\
17.4\end{array}$ & $\begin{array}{l}4.8 \\
4.6 \\
5.6 \\
3.5\end{array}$ & $\begin{array}{l}10.4 \\
10.8 \\
10.8 \\
11.2\end{array}$ & $\begin{array}{l}3.0 \\
1.9 \\
3.0 \\
2.7\end{array}$ & $\begin{array}{l}\mathbf{0} \\
\mathbf{0} \\
\mathbf{0} \\
\mathbf{0}\end{array}$ \\
\hline $\begin{array}{lr}\text { September } & 7,1941 \\
\text { October } & 1,1941 \\
\text { October } & 10,1941 \\
\text { January } & 9,1942\end{array}$ & $\begin{array}{l}\mathrm{T} \\
\mathrm{T} \\
\mathrm{T} \\
\mathrm{T}\end{array}$ & $\begin{array}{l}\text { Multiple myeloma. } \\
\text { Progressive renal } \\
\text { insufficiency }\end{array}$ & $\begin{array}{l}0.519 \\
0.563 \\
0.744 \\
0.475\end{array}$ & $\begin{array}{l}0 \\
0 \\
7.3\end{array}$ & $\begin{array}{l}100 \\
100 \\
99+ \\
92.7\end{array}$ & $\begin{array}{l}\mathbf{0} \\
\mathbf{0} \\
\mathbf{0} \\
\mathbf{0}\end{array}$ & $\begin{array}{c}98 \\
100 \\
99+ \\
91.2\end{array}$ & $\begin{array}{l}2.0 \\
0 \\
1.5\end{array}$ & $\begin{array}{l}\mathbf{0} \\
\mathbf{0} \\
\mathbf{0} \\
\mathbf{0}\end{array}$ \\
\hline
\end{tabular}


chemical method. In 12 others, electrophoresis gave a slightly higher value. In 3 of the 22 analyses, there was a difference of 5 points, in 1 , a difference of 6 , in the results obtained by the 2 methods. The difference was less than 5 points in each of the other pairs of analyses.

The results of electrophoretic analyses alone are shown in Table II. No fibrinogen was demonstrable in any of the specimens. The high proportion of globulin in the urine of the patients with rapidly progressing nephrotic nephritis ( $S$ and $Q$, Table II) was due especially to high percentages of gamma globulin. The globulin in the urine of the patient with slowly progressing nephrotic nephritis was about equally divided among the alpha, beta, and gamma fractions ( $M$, Table II). In the urine of patient $A$, with lipoid nephrosis, the small proportion of gamma globulin is very striking. Most of the protein in the urine of $T$ (multiple myeloma) moved like a beta globulin.

\section{DISCUSSION}

The close agreement of the results obtained by the 2 methods of analysis indicates that the fractionation and chemical method which we have used is reliable, and, when the concentration of protein in the urine is in the neighborhood of 0.4 grams per cent or more (1), the proportion of albumin and globulin may be determined with a degree of accuracy which is adequate to detect the differences which we have considered to be significant.

In comparing the $\mathrm{Kjeldahl}$ and electrophoretic methods, it is important to bear in mind that, so far as we can tell, differences of a few points are of little significance, although if they are expressed in terms of percentage, the variations between the results might seem to be great. Our previous chemical, clinical, and pathological studies of a long series of cases indicated that high or low concentrations of globulin in the urine for prolonged periods are significant in relation to the collection of protein coagula in the kidneys, in glomeruli or tubules or in both. It was found that there is what may be called a critical level for the precipitation of protein in the kidney in those urines with high protein concentrations in which the percentage of globulin lies in the neighborhood of 30 to 35 per cent of the total protein. Due partly to the limitations of the chemical method when applied to the small quantities of protein found in some urines, it was impossible to evaluate the significance between small differences in the percentage of globulin, such as the difference between 5 and 10 per cent globulin or the difference between 30 and 35 per cent. Since, however, many of the analyses were continued at weekly intervals for many months, it eventually became evident that concentrations of 5 to 25 per cent of globulin in the urine were below the critical level in relation to precipitation of urinary protein in the kidney, and it became equally evident that concentrations of 30,35 , and 40 per cent were above this level and were associated with the presence of protein coagula in the kidneys.

It is self-evident that errors inherent in a chemical procedure, expressed in absolute percentages of the total, increase as the quantities of material analyzed decrease below the optimum. Therefore, the results of globulin determinations by the chemical and electrophoretic methods are more significant when expressed in terms of their order of magnitude rather than in terms of the absolute percentage variation between the two. ${ }^{2}$

It is well-known that in the presence of chronic proteinuria, the renal insufficiency which develops in some cases is due in part to the accumulation within glomeruli and tubules of varying amounts of hyaline material which resembles precipitated or coagulated serum protein. In others (lipoid nephrosis) exhibiting equal or greater proteinuria, coagula may never form in the kidneys and progressive renal failure may never develop. Evidence obtained from chemical analysis of urinary proteins indicates that the rate of progress of

\footnotetext{
2 For example, the specimen "November 22, 1941, S," Table I, was found by both methods to contain a high percentage of globulin, 31 per cent by the chemical method and 37 per cent by electrophoresis. This is a difference of 6 points or an absolute variation of 19 per cent. Specimen "February 22, 1942, A," Table I, was found by both methods to contain a low proportion of globulin, 17 per cent by the electrophoretic and 21 per cent by the chemical method. This smaller variation of 4 points, expressed in percentage, is an apparent difference of 24 per cent. The difference between 35 and 36 is a variation of 2.5 per cent, while a similar difference of one point between 2 and 3 is a variation of 50 per cent. It is therefore obvious that it would be misleading to express the differences between the results of chemical and electrophoretic analysis of urinary protein in terms of percentage.
} 
renal failure of this type is closely associated with the duration and degree of concentration of globulin in urine which contains total protein in high concentration (1). In lipoid nephrosis, and in other cases of chronic nephritis during periods of stationary renal function, high concentrations of globulin were rarely found in the urine. The electrophoretic analyses gave similar results, higher proportions of globulin being found in the more rapidly progressing cases, and low globulin concentration in the case of nephrosis with normal renal function.

The electrophoretic analyses showed in addition that in the urine of the 2 most rapidly progressing cases of renal insufficiency, gamma globulin was especially abundant (Table II, patients $S$ and $Q$ ). The gamma globulin was considerably lower in the urine of patient $M$, and the progress of renal insufficiency has been a good deal slower in this case. The urine of the patient with lipoid nephrosis, and normal renal function for over 2 years, contained low concentration of total globulin by both methods of analysis, and by electrophoresis, gamma globulin was very low (patient A). Longsworth and MacInnes (7) and Luetscher (8) have also found low concentrations of gamma globulin in a few specimens of "nephrotic" urine which they examined electrophoretically. Inasmuch as gamma globulin is the fraction most easily precipitated by any of the usual protein precipitants, it might be expected that the concentration of this protein would be particularly concerned in precipitation within the kidney.

The Bence-Jones protein in the urine of the patient with multiple myeloma and renal insufficiency (Table II, patient T) behaved electrophoretically like a beta globulin. The papers of McFarlane (9), Longsworth, Shedlovsky, and MacInnes (10), Kekwick (11), and Gutman and associates (12), show that increased amounts of protein, with mobilities like beta or gamma globulins, occur in the blood of some cases of multiple myeloma.

The absence of demonstrable amounts of fibrinogen in the urines analyzed electrophoretically is especially interesting because the nephritis did not begin in any of the cases as acute hemorrhagic nephritis. We have already pointed out that in cases of this type (progressing nephrotic nephritis), most of the protein precipitated in the kid- ney does not resemble fibrin microscopically; and, in the glomeruli, it collects in an intercapillary position which is different from the location of the fibrin clots which can be readily identified in Bowman's spaces in some cases of acute hemorrhagic nephritis (1).

\section{SUM MARY}

The relative percentage of globulin in samples of a series of 24-hour specimens of nephritic urine was determined by a chemical method and by the electrophoretic moving boundary method of Tiselius. The concentration of total protein in the specimens varied from 0.450 to 3.45 grams per cent. The results obtained by the 2 methods agreed closely.

In the present small series of electrophoretic determinations, the concentration of gamma globulin in particular was high in urine of patients whose renal insufficiency was progressing rapidly, and the same fraction was very low in the urine of a patient with chronic lipoid nephrosis and normal renal function.

The absence of demonstrable quantities of fibrinogen in the urine of the patients with progressing nephrotic nephritis tends to confirm our previous conclusion that the hyaline materials which collect in glomeruli and tubules of these cases are probably derived from globulins other than fibrinogen.

The Bence-Jones protein in the urine of a patient with multiple myeloma and renal insufficiency behaved electrophoretically like a beta globulin.

We are indebted to Mr. Edward Leszcynski for assistance in electrophoretic analyses, and to Dr. Mary V. Buell for helpful advice.

\section{BIBLIOGRAPHY}

1. Blackman, S. S., Jr., Goodwin, W. E., and Buell, M. V., On the relation between the concentration of total protein and of globulin in the urine and the pathogenesis of certain renal lesions in Bright's disease. Bull. Johns Hopkins Hosp., 1941, 69, 397.

2. Tiselius, A., A new apparatus for electrophoretic analysis of colloidal mixtures. Trans. Faraday Soc., 1937, 33, 524.

3. Howe, P. E., The relative precipitating capacity of certain salts when applied to blood serum or plasma and the influence of the cation in the precipitation of proteins. J. Biol. Chem., 1923, 57, 241. 
4. Longsworth, L. G., and MacInnes, D. A., Electrophoresis of proteins by the Tiselius method. Chem. Rev., 1939, 24, 271.

5. Longsworth, L. G., Recent advances in the study of proteins by electrophoresis. Chem. Rev., 1942, 30, 323.

6. Davis, B. D., Unpublished data.

7. Longsworth, L. G., and MacInnes, D. A., An electrophoretic study of nephrotic sera and urine. J. Exper. Med., 1940, 71, 77.

8. Luetscher, J. A., Electrophoretic analysis of plasma and urinary proteins. J. Clin. Invest., 1940, 19, 313.
9. McFarlane, A. S., Behavior of pathological sera in ultracentrifuge. Biochem. J., 1935, 29, 1175.

10. Longsworth, L. G., Shedlovsky, T., and MacInnes, D. A., Electrophoretic patterns of normal and pathological human blood serum and plasma. J. Exper. Med., 1939, 70, 399.

11. Kekwick, R. A., The serum proteins in multiple myelomatosis. Biochem. J., 1940, 34, 1248.

12. Gutman, A. B., Moore, D. H., Gutman, E. B., McClellan, V., and Kabat, E. A., Fractionation of serum proteins in hyperproteinemia, with special reference to multiple myeloma. J. Clin. Invest., 1941, 20, 765. 